\title{
sciendo QUALITY ASSESSMENT OF E-COMMERCE SERVICE IN THE CONTEXT OF CUSTOMER EXPIRIENCES
}

doi:10.2478/mape-2018-0080

Date of submission of the article to the Editor: 05/2018

Date of acceptance of the article by the Editor: 07/2018
MAPE 2018, volume 1, issue 1, pp. 635-640

\author{
Dr. Aleksandra Radziszewska \\ Czestochowa University of Technology, Poland
}

\begin{abstract}
With rapid growth of the Internet, companies adopted the new information and communication technology to offer e-services to their customers. This paper addresses e-service quality issue in the electronic marketplace. Service quality of e-retailers has been recognized as an important factor in determining success of e-commerce ventures. The objective of this research is to develop a theoretical, comprehensive, and measurable framework for assessing the quality of ecommerce services and to indicate factors, which are significant for customers satisfaction and high quality online shopping experiences. This paper reviewed the most recognized evaluation criteria, which are used in different e-commerce websites, and proposes a general comprehensive framework for evaluating the quality of any e-commerce service regarding to two main areas: website features and customer service in e-commerce platform. The detailed list of quality attributes in both assessment areas was derived from the reviewed literature. The survey and analysis described in this paper enable a better understanding of the influence these quality attributes on the main quality assessment categories. The results provide an important foundation for the understanding of quality in e-commerce services that will allow to assess the strengths and weaknesses of each e-commerce service. This paper concludes by discussing the findings of this study and highlighting areas for the future research.
\end{abstract}

Keywords: e-service quality, e-commerce, quality assessment, customer experiences

\section{INTRODUCTION}

E-commerce is considered an excellent alternative for companies to reach new customers. Online consumers have a wider range of choices in selecting products and services, and highly competitive prices. As a result, competition between different Websites is high in order to attract the users' attention and make them repeat a visit. In this situation, it is generally not easy for online retailers to gain competitive advantages based only on a cost leadership strategy (Jun et al., 2004). Emerging online retailing has started to change shopping habits of individuals. Following these developments, researchers have started to study the concepts of electronic retail services and their quality (Zehir and Sadikoglu, 2012). Many researchers point out that to deliver a superior service quality is one of the key determinants of online retailers' success (Zeithaml et al., 2002) and it is a major driving force on the way to long-term success and competitive advantage (Fassnacht and Koese, 2006).

Service quality is "the comparison between perceived expectations of a service and perceived performance" (Wolfinbarger et al., 2003). The best known approach for measuring service quality is the SERVQUAL model (Parasuraman et al., 1988). The original five dimensions of SERVQUAL are: tangibles, reliability, responsiveness, assurance and empathy. However, SERVQUAL focuses on the traditional buyer-seller interaction, but does not take into account the interaction between customer and website, which is one unique character of e-commerce service quality. Existing studies on e-service quality mostly pay attention on identifying the elements that recognize customers' perception of service quality, and building models that outline the differences between customers' expectations and the real service experience (Zehir and Narcıkara, 2016). Service quality in e-commerce can be defined as 'the consumers' overall evaluation and judgment of the excellence and e-service 
quality offerings in the virtual marketplace" (Santos, 2003). Scientists emphasize different elements and dimensions of e-commerce service quality: quality of service provided, customer service, management of processes, ease of use, the quality of information and design of the website (Qin et al., 2008); responsiveness and security (Chiu et al., 2009); convenience, reliability, responsiveness, and assurance (Yang et al., 2009); security, usefulness, responsiveness, and receptiveness (Kim et al., 2012); website navigation and clear layout of information, ease of use, content, real-time support, reliability, security, design and ease search (Davidavičienè and Tolvaišas, 2011); interaction, responsiveness and usefulness (Anderson and Swaminathan, 2011). Alzola and Robaina (2010) proposed only two major phases of the evaluation of e-services: phase before and phase after the sale, and pointed out importance of added value. Due to the risk of purchasing a product online from an unfamiliar vendor, e-trust remains a critical issue in an electronic transaction (Hong and Cho, 2011).

Based on the review of e-commerce service quality evaluation criteria the following hypotheses for the causal relationship between the e-commerce service quality and its resulting customer satisfaction and sopping experiences have been proposed:

Hypothesis $1(\mathrm{H} 1)$. Website features of e-commerce platform have a positive effect on high quality customer experiences in online shopping.

Hypothesis $2(\mathrm{H} 2)$. Customer service in e-commerce platform has a positive effect on high quality customer experiences in online shopping.

The objective of this research is to develop a theoretical, comprehensive, and measurable framework for assessing the quality of e-commerce services and to indicate factors, which are significant for customers satisfaction and high quality online shopping experiences. This paper reviewed the most recognized evaluation criteria, which are used in different ecommerce websites, and proposes a general comprehensive framework for evaluating the quality of any e-commerce service regarding to website features and customer service in ecommerce platform.

The paper is organized as follows. After review of evaluation criteria, which are used regarding to assessment of e-commerce services quality, the paper describes the methodology of research and defines the dimensions of the proposed framework and its indicators. Than the results of research have been presented and discussed. The last section concludes the paper and suggests some future work.

\section{METODOLOGY OF RESEARCH}

The analysis of literature enabled to identify key elements for e-commerce websites quality evaluation. Based on the previous research discussed above and literature review, the two main areas of e-commerce service quality assessment have been selected: website features and customer service. Category of website features takes into consideration: website functionality, easy navigation, information accessibility and actuality, website content, reliability, website attractiveness and design. In contrast, customer service is connected with such variables as: simplicity of product search, ordering, and payment process, conditions of product return, delivery time, rapid response, rapid error handling, possibilities of order status tracking, online help and customer support, easy contact and communication with seller, recommendations and help by product choice, product accessibility, personalization possibilities, transaction security and privacy. The proposed model of e-commerce service quality assessment and its criteria have been presented in Table 1.

Questions have been grouped in two categories: website features (6 questions) and customer service (12 questions). The survey was conducted from January to March 2018. The questionnaires were randomly dispatched to e-commerce users via e-mail and messenger. 
Table 1

The proposed model of e-commerce service quality assessment

\begin{tabular}{|l|l|}
\hline \multicolumn{1}{|c|}{ Category of quality assessment } & \multicolumn{1}{c|}{ Detailed criteria } \\
\hline Website features & functionality \\
& easy navigation \\
information accessibility and actuality & content \\
& reliability \\
& attractiveness and design \\
\hline Customer service & simplicity of product search, ordering, and payment \\
& conditions of product return \\
& delivery time \\
& rapid response \\
& rapid error handling \\
& possibilities of order status tracking \\
& online help and customer support \\
& easy contact and communication with seller recommendations and \\
& help by product choice \\
& product accessibility \\
& personalization possibilities \\
& transaction security and privacy \\
\hline
\end{tabular}

Totally 230 questionnaires were distributed to potential respondents, and 172 of them replied. Among the 172 respondents, 21 of them indicated that they have little or no experience of multi-channel transactions and online shopping, and 11 questionnaires were uncompleted. The remaining 140 respondents are the basis of the study. 140 completed questionnaires have been used in the analysis of data, by using V-Cramer's Correlation Coefficient.

Respondents included $57 \%$ males and $43 \%$ females. $46 \%$ of the respondents were under the age of $25,27 \%$ were ages $26-40,19 \%$ were ages $41-55$, and $8 \%$ were over age 55 . All respondents browse regularly e-commerce sites, and have experience of online shopping. Indicating the causes of online shopping the respondents highlighted a lower price of the goods $(68 \%)$, convenience and simplicity $(84 \%)$, lack of time $(42 \%)$, greater diversity of goods (56\%), and better opportunities of optimal product choice in the Internet $(74 \%)$, easy comparison of products and prices (62\%). Table 2 shows the details of the respondents characteristics.

Table 2

Characteristic of the respondents

\begin{tabular}{|c|c|c|}
\hline \multicolumn{2}{|r|}{ Profile of the respondents } & $\begin{array}{l}\text { Percent } \\
{[\%]}\end{array}$ \\
\hline Gender & $\begin{array}{l}\text { Male } \\
\text { Female }\end{array}$ & $\begin{array}{l}57 \\
43\end{array}$ \\
\hline Age & $\begin{array}{l}18-25 \\
26-40 \\
41-55 \\
\text { over } 55\end{array}$ & $\begin{array}{c}46 \\
27 \\
19 \\
8\end{array}$ \\
\hline $\begin{array}{l}\text { Online shopping } \\
\text { motivation }\end{array}$ & $\begin{array}{l}\text { lower price of the goods } \\
\text { convenience and simplicity } \\
\text { lack of time } \\
\text { greater diversity of goods } \\
\text { better opportunities of optimal product choice } \\
\text { easy comparison of products and prices }\end{array}$ & $\begin{array}{l}68 \\
84 \\
42 \\
56 \\
74 \\
62\end{array}$ \\
\hline
\end{tabular}

In questionnaire, each respondent determines the importance of every factor with a five-point Likert scale (very unimportant, unimportant, neutral, important, and very important). Correlation analyze was used to estimate the unique effect of web site features (website functionality, easy navigation, information accessibility and actuality, website content, 
reliability, website attractiveness and design) and customer service (simplicity of product search, ordering, and payment process; conditions of product return; delivery time; rapid response; rapid error handling; possibilities of order status tracking; online help and customer support; easy contact and communication with seller; recommendations and help by product choice; product accessibility; personalization possibilities; transaction security and privacy) on consumers' satisfaction level in e-commerce.

\section{RESULTS}

Influence of website features and customer service (Table 1) on online shopping quality assessment have been analyzed with help of V-Cramer's Correlation Coefficient. Regarding the importance of the website features, this research clearly shows that reliability is the most important factor $(\mathrm{V}=0.947)$. These results correspond with the conclusions of prior studies and confirm that reliability has a strong influence on the perceived quality of e-commerce service (Bauer et al., 2005; Wolfinbarger and Gilly, 2003). The results confirm that the website functionality and attractiveness are important elements for the consumer and becoming a critical factor. The conducted survey of e-commerce website quality evaluation confirms the results of other scientists (Parasuraman et al. 2005). For surveyed consumers the most important factors are: easy navigation $(\mathrm{V}=0.871)$, website functionality $(\mathrm{V}=0.823)$, information accessibility and actuality $(\mathrm{V}=0.817)$. Less important are website content $(\mathrm{V}=$ $0.736)$ and its attractiveness and design $(\mathrm{V}=0.721)$.

Regarding the importance of customer service in e-commerce, transaction security and privacy have the great impact on customers' shopping experiences and quality level in ecommerce $(\mathrm{V}=0.892)$. The obtained result indicates that security is fundamental for online shopping, especially when it comes to electronic payments. Privacy is one of the most important in the evaluation of an online service quality, and one of those that have the most influence on customer satisfaction. But this research shows the smaller importance of this dimension in comparison with website reliability. This fact is possibly due to the technological advances of recent years concerning online purchase payment security and there being a growing tendency in the number of customers who are familiar with this type of electronic transactions (Udo et al., 2010). An explanation may be the fact that younger consumers ( $73 \%$ of surveyed customers were between 18 and 40 years old) perceive less risk in this type of purchases than older consumers.

The data analysis also demonstrate that personalization possibility $(\mathrm{V}=0,729)$, and product accessibility $(V=0,723)$ are very important for satisfaction assessment in online- shopping. The other most important factors are: easy contact and communication with seller $(\mathrm{V}=$ $0,712)$, rapid response $(V=0,697)$, rapid error handling $(V=0653)$, simplicity of product search, ordering, and payment process $(\mathrm{V}=0,627)$, and conditions of product return $(\mathrm{V}=$ $0,587)$. The assessment of online shopping revealed the importance of the delivery time $(\mathrm{V}=$ $0,611)$, and the order status tracking possibilities $(V=0,531)$. Online help and customer support systems $(V=0,523)$ are the next important predictor of online shopping satisfaction. The data indicate that recommendation and help by product choice $(\mathrm{V}=0,467)$ are of less practical significance to e-customers satisfaction assessments.

According to conducted analysis all considered factors have positive influence on customer experiences in online shopping. Therefore, both research hypothesis $(\mathrm{H} 1$ and $\mathrm{H} 2)$ are accepted. There is a positive correlation between website features and high quality customer experiences in online shopping $(\mathrm{H} 1)$, and there is a positive correlation between customer service in e-commerce and high quality customer experiences in online shopping (H2).

Personalization, customer trust connected with transaction security, and e-commerce website reliability are key factors for a successful customer satisfaction management in online shopping. Customers are aware of all the information that they give away to ecommerce company about their purchase histories, habits or personal data and demand customized communications, personalization of shopping process and reduction of 
perceived risk connected with online transaction by ensuring its security and e-commerce website reliability

\section{DISCUSSION}

The explosion of the Internet has determined the need of measurement criteria to evaluate the aspects related to the quality of web applications. It is important for each contemporary company to assess the quality of its e-commerce service, in order to improve its services over time and benchmark against competitors and best practices.

It is necessary to analyze and define the potential requirements of consumers taking into account the fact that the website should eliminate the lack of real buyer-seller relationship. High quality e-commerce website possesses interactive elements and exploits advantages of virtual environment, which refers first of all to the convenience of online purchase and benefits from the transaction cost saving and time saving connected with minimizing delivery time.

There are two phases of buying process, connected with customer's experiences before and after of product ordering. The first phase begins at the moment when a potential consumer enter the website. At this stage of purchase process the potential buyer evaluates such elements as: website functionality, easy navigation, information accessibility and actuality, website content, website reliability, website attractiveness and design. At this stage consumer's experiences are influenced not only by e-commerce website features, but also by factors connected with service quality such as: simplicity of product search, ordering, and payment process, easy contact and communication with seller, recommendations and help by product choice, product accessibility, personalization possibilities, transaction security and privacy. This phase ends after the payment made. Then begins the second phase in which the consumer expects that the products will be as described, the convenient on time delivery as promised, and rapid solving of emerging problems. At the second stage of purchase process consumer's satisfaction is influenced first of all by factors connected with service quality, such as: conditions of product return, delivery time, rapid response, rapid error handling, possibilities of order status tracking, online help and customer support, easy contact and communication with seller. The model of e-commerce website and e-commerce service quality evaluation assesses all processes and phases of e-shopping and provides logical and systematic structure of quality assessment.

\section{CONCLUSION}

The Internet created a new business environment far different from anything that has come before. The deployment of recent information and communication technologies shaped new era in business and retail. This paper reviewed the most recognized evaluation methods which were used in evaluating the quality of different websites, and proposes a comprehensive framework for assessing the quality of e-commerce services. This paper has determined the factors that assess the quality of e-commerce service, identifying and rating the main quality attributes to this application domain. The two main areas of consumers satisfaction assessment in e-commerce are: website features and consumer service quality. The list of quality attributes was derived from the reviewed literature. The survey and analysis described in this paper enabled a greater understanding of the relations and influences these quality attributes have on the main quality assessment categories. The results provide an important foundation for the understanding of quality in e-commerce services that will allow to assess the strengths and weaknesses of each e-commerce service in order to know where to focus further development to achieve the high quality needed for e-commerce success.

Some limitations of this research should be acknowledged and directions for future studies should also to be suggested. Convenience sampling does not permit results to be generalized to a larger population. A future study should try to validate and generalize the 
findings of this study by using a wider sample. Future research lines could be developed to evaluate if the quality of e-commerce services differs according to other factors connected with different characteristics of online shoppers.

\section{REFERENCES}

Alzola, L. and Robaina, V. (2010). The Impact of pre-sale and post-sale Factors on Online Purchasing Satisfaction: a Survey. International Journal of Quality and Reliability Management, 27(2), pp. 121-137.

Anderson, R. and Swaminathan, S. (2011). Customer satisfaction and loyalty in e-markets: A PLS path modeling approach. Journal of Marketing Theory Practice, 19, pp. 221-234.

Bauer, H., Hammerschmidt, M. and Falk, T. (2005). Measuring the quality of e-banking portals. International Journal of Bank Marketing, 23(2), pp. 153-175.

Chiu, C., Chang, C., Cheng, H. and Fang, Y.H. (2009). Determinants of customer repurchase intention in online shopping. Online Information Review, 33, pp. 761-784.

Davidavičienè, V. and Tolvaišas, J. (2011). Measuring quality of ecommerce web sites: case of Lithuania. Economics and Management, 16, pp. 723-729.

Fassnacht, M. and Koese, I. (2006). Quality of electronic services: Conceptualizing and testing a hierarchical model. Journal of Service Research, 9(1), pp. 19-37.

Hong, I. and Cho, H. (2011). The impact of consumer trust on attitudinal loyalty and purchase intentions in B2C e-marketplaces: Intermediary trust vs. seller trust. International Journal of Information Management, 31, pp. 469-479.

Jun, M., Yang, Z. and Kim, D. (2004). Customers' perceptions of online retailing service quality and their satisfaction, International Journal of Quality and Reliability Management, 21(8), pp. 817840.

Kim, C., Galliers, R., Shin, N., Ryoo, J. and Kim, J. (2012). Factors influencing Internet shopping value and customer repurchase intention. Electronic Commerce Research and Application,11, pp. 374-387.

Pasuraman, A. and Berry, L.L. (1988). SERVQUAL: A Multiple item scale for measuring customer perception of service quality. Journal of Retailing, 64, pp. 12-40.

Parasuraman, A., Zeithaml, V. and Malhotra, A. (2005). E-S-QUAL: A Multiple-Item Scale for Assessing Electronic Service Quality. Journal of Service Research, 7(3), pp. 13-33.

Santos, J. (2003). E-service quality: a model of virtual service quality dimensions. Management Service Quality, 13(3), pp. 233-246.

Qin, S., Zhao, L., Yong-tao S. and Ting Ch. (2008). Conceptualizing Consumers' Perceptions of Ecommerce Quality. International Journal of Retail \& Distribution Management, 36(5), pp. 360374.

Udo, G., Bagchi, K. and Kirs, P. (2010). An assessment of customers' e-service quality perception. Satisfaction and intention. International Journal of Information Management, 30, pp. 481-492.

Wolfinbarger, M. and Gilly, M. (2003). E-tail: Dimensionalizing, measuring and predicting e-tail quality. Journal of Retailing, 79(3), pp. 183-198.

Yang, H., Wu, C. and Wang, K. (2009). An empirical analysis of online game service satisfaction and loyalty. Expert Systems Applications, 36, pp. 1816-1825.

Zehir, C. and Narcıkara, E. (2016). E-Service Quality and E-Recovery Service Quality: Effects on Value Perceptions and Loyalty Intentions. Procedia - Social and Behavioral Sciences, 229, pp. 427443.

Zehir, C. and Sadikoglu, E. (2012). Relationships among total quality management practices: An Empirical study in Turkish industry. International journal of Performability Engineering, 8 (6), pp. 667-678.

Zeithaml, A. (2002). Service Exellence in Electronic Channels. Managing Service Quality, 12(3), pp. 13-138. 